\title{
Difficulties in Writing Business English Correspondence
}

\author{
Neti Rosiana Fadilah \\ Asmi Citra Nusantara \\ neti88.english@gmail.com
}

\begin{abstract}
The title of this research was the difficulties in writing business English correspondence at fourth Secretary Semester students in ASMI Citra Nusantara Banjarmasin Academic Year 2018-2019 which was aimed at knowing the difficulties of Writing Business English Correspondence. The population was 15 students or whole of the fourth Secretary Semester students and the researcher conducted the data using descriptive qualitative research that employs descriptive qualitative method. The data of this study were obtained by using questionnaire was divided into two parts; they are background of the respondent and surveyed the difficulty by using Likert-Scale. The scale ranged from: "Strongly Agree, Agree, Neutral, Disagree and Strongly Disagree". Writing difficulties at Business English Correspondence at fourth semester students varied in the result which related to the Linguistic difficulty, like wide range of vocabulary usage. They have to enlarge the vocabulary meaning, using appropriate or formal vocabulary or sentences in Business English Correspondence. The respondents also gave their suggestion to change their difficulties like, changed their learning English method especially in writing business English correspondence.

Key words: Difficulties, Writing, Business English Correspondence.
\end{abstract}

\section{INTRODUCTION}

Communication is necessary in adapting to the environment; no communication there is any life in the world. As stated by Newstrom \&Keith Davi's, communication is the transfer of information from one. It is a way of reaching others by transmitting ideas, feelings, thoughts, facts, and values. Meanwhile according to Keyton 2001, communication could be defined as the process of transmitting information and mutual understanding from one person to another. The primary of human is social beings that cannot live alone and require communication. Human being are not passive, they always interpret meaning and react as they "suppose to be".

Communication must be done appropriately so it will not lead to different perceptions between the information giver and the recipient of the information. Communication can be 
DIFFICULTIES IN WRITING BUSINESS ENGLISH CORRESPONDENCE AT FOURTH

SECRETARY SEMESTER STUDENTS

NETI ROSIANA FADILAH

conveyed through symbols. There are many symbols that are used to communicate, they are letters, colors, numbers, pictures traffic light, etc. the symbols can be used as a communication that gives certain information. In addition, communication can also be through by language. Lyon (1981: 18) defines that language is a symbol designed for the purpose at communications. People not only speak but also express their idea and keep the relationship each other. Meanwhile Wardhaugh explains that "Language allows people to say something to each other and express communicate needs (Wardhaugh, 1992: 8). There are many languages used in communication. In Indonesia, learning Indonesian and English are bound to be learned and be a language of communication. English has become familiar language for everyone to use, even it has become a key to grasp all aspects in business, politics, social or cultural.

Nowadays, English becomes a universal language. The one factor of successful business is a good communication in English. Work requires communication; in hence communication is regarded as the lifeblood of business. Through communication brings dynamism in organization activities and helps in achieve the goals. Language as a means of communication whether it is verbal or non-verbal, written or spoken cannot be apart from culture as means of encoding a community's knowledge belief and values (Holmes, 2001:329) besides the language one uses expresses what he knows, he feels, and he believes. It is important for people to master English orally and written, in order to be able to communicate and socialize with the world community. In the business world in Indonesia, English is used by companies as one of the terms of language the communication that must be mastered in work. Prospective workers are guided to be able to communicate both oral and written in English.

Oral communication is direct conversation between two or more people to convey ideas or opinions and has a feedback. Oral communication is effective to extent the mind and purpose, but written communication also necessary because there are many benefits, which can be used as authentic evidence, reminders, and evidence of black and white that has a strong legal basis than oral communication. According to Troyka states that writing is understood as a way of communicating a message to the reader for a purpose (in Muth'im, 2007:2). Hammond states that 


\section{INTENSIVE JOURNAL}

http://ojs.uniska-bjm.ac.id/index.php/EJB

E-ISSN 1513567470

writing as a complex task which requires everything from getting your spelling right to making your voice distinctive enough to be heard (in Muth'im, 2007:2). Judy L Minler mention that writing is also a social endeavor, a way of communicating with others, informing them, persuading them, and debating with them (Judy L Minler, Robert, 2001: 7). It means that writing is an activity to express ideas, issues, events, feeling or thinking to the others through written form. Based on the statements above, it can be concluded that writing means to express ideas, to convey a message to the reader, which needs considerable components. Therefore, in the context of the teaching of writing in English, students need to learn how to communicate in written English as a way of sharing observation, information, thoughts, or ideas with themselves and others.

ASMI Citra Nusantara Banjarmasin students are required be able to communicate in oral and written English in order to compete with other prospective workers, especially for the Secretary major, they were not only be accuse in speaking English mastered but also writing English letters. According to SAP, the fourth Semester Secretary Major "Secretary Students are able to write Business English Correspondence". In ASMI Citra Nusantara Banjarmasin, students in secretary major are taught many kinds of business letter, like order, complain, inquiry, offer or sale letter etc. Same as according to Bly (2004) there are many kinds of business letter, they are order letter, inquiry letter, request letter, recommended letter, adjustments etc. The secretary students have to write clear, polite and professional business letter so that the aims of the letter could be achieved. They have to able to string the words into good business English sentences and in accordance with the rules of writing business English letters so that the company's relations understand the purpose of the letter. According to Insley Robert 2016 "letters are formal documents that are typically used to convey information to communication partners outside the organization". The goal is to either share neutral, good, or negative news or to persuade readers to a specific course of action. Business letter is the principles that are used by a business firm to keep in touch with its customers. As stated in Business Correspondent's book, the statements written in the letter should be accurate to, the best of the sender's knowledge. Accuracy demands that there are no errors in the usage of language - in grammar, spellings, punctuations etc. An accurate letter is always appreciated (Loughead, 2003). 
DIFFICULTIES IN WRITING BUSINESS ENGLISH CORRESPONDENCE AT FOURTH

SECRETARY SEMESTER STUDENTS

NETI ROSIANA FADILAH

Based on the observation, the researcher found that the students in Secretary Major still got difficulties in Writing Business English Correspondence. Most of Secretary Students using their own sentence then translate to English without grammatical rules and English structure. They still using inappropriate words in writing English business and also forming long sentences so it makes difficult to understand. As defined in Cambridge Dictionary, the word problem means a situation, person or thing that needs to be dealt with or solved.

\section{METHODOLOGY}

In this research, the researcher conducted this research using descriptive qualitative research that employs descriptive qualitative method. Nawawi (1994) states that Descriptive qualitative method can be defined as a procedure in solving problem that is investigated by describing or drawing the subject condition or the research object ( someone, institution, society, etc.) in the present tense based on reality. Qualitative research is seeking type of research. According to Creswell (1998) "A qualitative study is defined as an inquiry process of

understanding a social, human problem”. Qualitative research is a general definition of many different methods used in understanding and explaining social phenomena and it can need the opinion about something according to his/her own knowledge. The participant of the research is the whole students of the Fourth Semester Secretary Program in Asmi Citra Nusantara Academic Year 2017-2018. The numbers of participants are 15 students, because the students in Secretary Major at fourth semester were 15 students and the technique to select the participant used purposive sampling technique as the source of the data. As stated by Sugiono (2009) population us a generalization region consisting of objects/subjects which have certain qualities and characteristics. Marguerite et.al (2006) said "purposive sampling technique is a common procedure used in qualitative research that identifies key informants of person who have specific knowledge about the topic being studied. The Instruments of data collection used in this research was questionnaire. The questionnaire is design to survey the problems in writing business English correspondence. The researcher distributes the questioner after the process of teaching and learning business English correspondence. A close-ended question format that used to limits the 


\section{INTENSIVE JOURNAL}

http://ojs.uniska-bjm.ac.id/index.php/EJB

E-ISSN 1513567470

participant's answer. After the data gathered, all questionnaires read by the researcher. The data was analyzed by Likert-Scale the questionnaire was divided into three parts as follows:

Part 1: Background of the respondents:

This part was design using close-ended questions to collect personal information, which consists of age, educational background and frequency of English used in daily life.

Part 2: this part surveyed the problems the problems in using a Five point Likert Scale. The scale ranged from: "Strongly Agree, Agree, Neutral, and Disagree"to"Strongly Disagree" as follows:

Table 1 Likert-Scale Range

\begin{tabular}{|l|l|}
\hline \multicolumn{2}{|l|}{ Range } \\
\hline Score & Opinion \\
\hline 1 & Strongly Disagree \\
\hline 2 & Disagree \\
\hline 3 & Neutral \\
\hline 4 & Agree \\
\hline 5 & Strongly Agree \\
\hline
\end{tabular}

Part 3: The opened-ended question to know the suggestion of how to solve of writing business English correspondence problem. The data was collected and analyzed with the statistical Package for the social Sciences (SPSS) program, which was used to compute the frequency distribution and percentage was used in the writing Business English Correspondence. To interpret the mean score results, the following formula was used.

Table 2 Mean Range

\begin{tabular}{|c|c|}
\hline \multirow[t]{2}{*}{ Mean Range $=$} & Maximum - Minimum $=\underline{5-1}=0.8$ \\
\hline & $\begin{array}{ll}\text { Range } & 5\end{array}$ \\
\hline Scale & Mean Range \\
\hline $5=$ very great need & $4.21-5.00$ \\
\hline $4=$ great need & $3.41-4.20$ \\
\hline $3=$ Moderate need & $2.61-3.40$ \\
\hline $2=$ Little need & 1.812 .60 \\
\hline $1=$ very little need & $1.00-1.80$ \\
\hline
\end{tabular}


DIFFICULTIES IN WRITING BUSINESS ENGLISH CORRESPONDENCE AT FOURTH

SECRETARY SEMESTER STUDENTS

NETI ROSIANA FADILAH

\section{FINDINGS}

After collecting the data, the researcher found the general background information of the respondent, problem and how to improve writing business English correspondence.

The result as follows:

Table 3. Age

\begin{tabular}{|l|l|l|}
\hline Age & Frequency & Percentage $(\%)$ \\
\hline $17-19$ & 3 & $20 \%$ \\
\hline $20-22$ & 12 & $80 \%$ \\
\hline$>23$ & 0 & 0 \\
\hline Total & 15 & $100 \%$ \\
\hline
\end{tabular}

Table 3 shows the most of the respondents were in 20-22 years old $70 \%$, then 3 respondents are in 17-19 years old.

Table 4. Education

\begin{tabular}{|l|l|l|}
\hline Education & Frequency & Percentage (\%) \\
\hline Vocational High School & 3 & $20 \%$ \\
\hline Senior High School & 11 & $73 \%$ \\
\hline Islamic Senior High School & 1 & $7 \%$ \\
\hline Total & 15 & 100 \\
\hline
\end{tabular}

Table 4 shows the $20 \%$ respondents graduated from vocational high school, $7 \%$ were from Islamic senior high school and then $73 \%$ graduated from Senior High School. It can be seen, that most of the Secretary students were not had basic to write Business English. They did not have a writing business English subject before. It means that they did not have experience in writing business English.

Table 5 English Skills Usage in Daily Life

\begin{tabular}{|l|c|c|}
\hline $\begin{array}{l}\text { Which English skill do } \\
\text { you use the most in your } \\
\text { life? }\end{array}$ & Frequency & $\begin{array}{l}\text { Percentage } \\
(\%)\end{array}$ \\
\hline Reading & 4 & $27 \%$ \\
\hline Writing & 1 & $7 \%$ \\
\hline Speaking & 2 & $13 \%$ \\
\hline Listening & 8 & $53 \%$ \\
\hline Total & 15 & $100 \%$ \\
\hline
\end{tabular}




\section{INTENSIVE JOURNAL}

http://ojs.uniska-bjm.ac.id/index.php/EJB

E-ISSN 1513567470

It can be seen above (table 5) that $27 \%$ the respondents admit reading skill as their skills that used in life frequently. $13 \%$ said that speaking as their skill to do in daily life. Then, 1 student said writing as her activity to do the most in daily life. And last, respondents represent listening as their master skill to do in life.

Table 6, Difficulties in English skills usage

\begin{tabular}{|l|c|c|}
\hline $\begin{array}{l}\text { Which English skill is the } \\
\text { most serious problem for you? }\end{array}$ & Frequency & Percentage (\%) \\
\hline Reading & 2 & $13 \%$ \\
\hline Writing & 8 & $53 \%$ \\
\hline Speaking & 3 & $20 \%$ \\
\hline Listening & 2 & $13 \%$ \\
\hline Total & 15 & $100 \%$ \\
\hline
\end{tabular}

Part 2: The problems in writing business English correspondence at Secretary Students in ASMI Citra Nusantara. The second part is observed and investigated the problems in writing business English correspondence at Secretary Students in ASMI Citra Nusantara by questionnaire. The findings are presented in the form of means, which were calculated into range using the followings criteria.

\begin{tabular}{|l|l|}
\hline $\begin{array}{c}\text { Mean Range }=\text { Maximum }- \text { Minimum } \\
5\end{array}$ S-1 $=0.8$ Range \\
\hline \multicolumn{1}{|c|}{ Scale } & Mean Range \\
\hline $5=$ Strongly Agree & $4.21-5.00$ \\
\hline $4=$ Agree & $3.41-4.20$ \\
\hline $3=$ Neutral & $2.61-3.40$ \\
\hline $2=$ Disagree & 1.812 .60 \\
\hline $1=$ Strongly Disagree & $1.00-1.80$ \\
\hline
\end{tabular}

As can be seen in Table 6, the most significant problem in English skills usage of participants was English writing skill, representing $53 \%$ of the total. A total of $20 \%$ of the 
DIFFICULTIES IN WRITING BUSINESS ENGLISH CORRESPONDENCE AT FOURTH

SECRETARY SEMESTER STUDENTS

NETI ROSIANA FADILAH

participants had problems in English speaking skill; meanwhile, 13\% of the participants had problems in English reading skill and 13\% had problems in English listening skill usage.

Table 7, Difficulties of Writing Business English Correspondence

\begin{tabular}{|c|c|c|c|c|c|c|c|c|c|}
\hline \multirow[t]{2}{*}{$\begin{array}{l}\mathrm{N} \\
\mathrm{O}\end{array}$} & \multirow[t]{2}{*}{ Description } & \multicolumn{5}{|c|}{$\begin{array}{l}\text { Rate Scale } \\
\text { Range }\end{array}$} & \multirow[t]{2}{*}{ Mean } & \multirow[t]{2}{*}{ S.D } & \multirow[t]{2}{*}{ D.A } \\
\hline & & 5 & 4 & 3 & 2 & 1 & & & \\
\hline 1 & $\begin{array}{l}\text { I'm not always remember how to write Date in } \\
\text { English }\end{array}$ & 3 & 5 & 7 & 0 & 0 & 3.73 & 3.08 & Neutral \\
\hline 2 & $\begin{array}{l}\text { I don't know the purpose of the article when I write } \\
\text { my business letter }\end{array}$ & 1 & 3 & 5 & 4 & 2 & 2.80 & 1.58 & Neutral \\
\hline 3 & $\begin{array}{l}\text { I cannot avoid using jargon and unfamiliar words } \\
\text { and phrases when I write my business letter }\end{array}$ & 2 & 4 & 5 & 2 & 2 & 3.13 & 1.41 & Neutral \\
\hline 4 & $\begin{array}{l}\text { I can't use appropriate words or business words in } \\
\text { my business letter }\end{array}$ & 2 & 3 & 6 & 4 & 0 & 3.20 & 2.24 & Agree \\
\hline 5 & $\begin{array}{l}\text { I can't write my business letter with all the } \\
\text { information necessary to make the point and } \\
\text { clarify whatever action the letter request }\end{array}$ & 2 & 6 & 7 & 0 & 0 & 3.67 & 3.32 & Agree \\
\hline 6 & $\begin{array}{l}\text { I can't choose words and phrases to set a positive } \\
\text { tone in my business letters }\end{array}$ & 1 & 4 & 9 & 1 & 0 & 3.33 & 3.67 & Agree \\
\hline 7 & $\begin{array}{l}\text { I'm not always use spell check and recheck when } \\
\text { my writing business letter before submit to the } \\
\text { lecturer }\end{array}$ & 0 & 3 & 5 & 5 & 2 & 2.60 & 2.12 & Disagree \\
\hline 8 & $\begin{array}{l}\text { I can't make my business letter clear, concise and } \\
\text { communicate. }\end{array}$ & 2 & 4 & 8 & 1 & 0 & 3.47 & 3.16 & Agree \\
\hline 9 & $\begin{array}{l}\text { In body of letter. In paragraph one or Introduction } \\
\text { paragraph, I can't make appropriate sentences in } \\
\text { Introducing the subject of the letter }\end{array}$ & 0 & 2 & $\begin{array}{l}1 \\
0\end{array}$ & 3 & 0 & 2.93 & 4.12 & Neutral \\
\hline 10 & $\begin{array}{l}\text { In body of letter. I can make second paragraph or } \\
\text { Main Part of the Letter states the main idea or the } \\
\text { reason for writing. I can't make it clear, concise, } \\
\text { complete, and to the point. }\end{array}$ & 3 & 4 & 5 & 3 & & 3.47 & 0.96 & Agree \\
\hline 11 & $\begin{array}{l}\text { In body of letter. I can't make concluding Part or } \\
\text { in third paragraph contains the conclusion of the } \\
\text { business letter. }\end{array}$ & 0 & 2 & $\begin{array}{l}1 \\
0\end{array}$ & 3 & 0 & 2.93 & 4.12 & Agree \\
\hline 12 & I don't have many vocabulary & 2 & 4 & 5 & 4 & 0 & 3.27 & 2.00 & Agree \\
\hline 13 & $\begin{array}{l}\text { I think my lecturer has not explain the material } \\
\text { thoroughly }\end{array}$ & & 1 & 2 & 4 & 9 & 1.80 & 3.56 & $\begin{array}{l}\text { Strongly } \\
\text { Disagree }\end{array}$ \\
\hline
\end{tabular}




\begin{tabular}{|c|l|c|c|c|c|c|c|c|l|}
\hline 14 & I need more time to write & 4 & 5 & 4 & 2 & & & & Agree \\
\hline 15 & $\begin{array}{l}\text { I can't use wide range of vocabulary in my } \\
\text { Business English Letter }\end{array}$ & 2 & 7 & 3 & 3 & 0 & & & \\
\hline 16 & I don't know the grammar (tenses) I used & 3 & 4 & 5 & 3 & 0 & 3.73 & Agree \\
\hline
\end{tabular}

It can be seen in table 7, Most of students stated that "I cannot use wide range of vocabulary in my business English letter", which was the main difficulty for them (Mean =3.53), it means the respondents have limited vocabulary; therefore the writer should have wide range vocabulary. He should know the other formality word, for example "We have all the items in stocks and are now making up the order", here "make up" is much more formal than "prepare".

Then followed by the difficulty "I can't use appropriate words or business words in my business letter" (Mean = 3.20), and "I can't make my business letter clear, concise and communicate" (Mean = 3.47). As stated in theory of Robert Insley, from the book Business Letter \& Memos from Communicating "Appropriate word in Business English Letter choice contributes to make clear, formal and effective letter. Careless word choice can lead to confusing message that result miscommunication. Familiar word help you get your point across without slowing down your reader. Then, in the similar book stated that the writer have to write concisely and clearly. The writer should careful not to include unnecessary detail, avoid using surplus words and phrases, because are those that do not affect message clarity when deleted with a shorter replacement. Therefore, eliminate the bureaucratic jargon, trite expression, clichés and technical jargon". Next, the respondent also agreed with statement, which was "in body of letter. I cannot make second paragraph or Main Part of the Letter states the main idea or the reason for writing" (Mean = 3.47). It means that the respondents have difficulties to write the necessary information, which obviously stated in Business Letters \& communicating in Business 2016 "Body paragraph(s). Present the supporting information and maintain a friendly tone". Next Problem is "I can't make it clear, concise, complete, and to the point". (Mean = 3.47) and "I can't write my business letter with all the information necessary to make the point and clarify whatever action the letter request" (Mean $=3.67)$. According to Clarity means avoid ambiguity and confusion, so it will be informative, simple and accurate while the sentences should be well constructed (Gao Jiayong, 2001). Then the 
DIFFICULTIES IN WRITING BUSINESS ENGLISH CORRESPONDENCE AT FOURTH

SECRETARY SEMESTER STUDENTS

NETI ROSIANA FADILAH

mean 3.47 I don't know the grammar (tenses) that I used to write was the sixth rank of problem faced by the respondent. Actually the solution was "Passive Voice has a function to soften the tone and maintain the harmonious communicative atmosphere in business dealing” (Ashley, A. A, 1992). It means that in proper expression at Business Correspondence, the use of passive voice set up correspondence more polite and friendly. The lowest mean score were. The respondent were neutral with the statement "I think my lecturer has not explain the material thoroughly $($ Mean $=$ 1.80) and I'm not always use spell check and recheck when my writing business letter before submit to the lecturer (Mean $=2.60$ ). According to the result above the significant problem in Writing Business English Correspondence related to the using wide range of vocabulary, stated to being clear, communication and concise.

In giving suggestions, 7 students said "I have to learn and remember the wide range of vocabulary" and "I have to enlarge my vocabulary, especially for synonym of the word because from knowing the synonyms, it means that I have tried to gain many vocabularies. Then other students said "I just wrote words from the Google translate without knowing other synonym of the words, so it makes me less in vocabulary and meaning. It will be conclude that the respondent need learn more vocabulary in wide range. So it similar with the statement from Cameron (2001:71) believes that building a useful vocabulary is central to learn foreign language at primary level. Vocabulary mastery is important in writing. Without enlarging their vocabulary, students cannot write successfully. Therefore anyone who learned a language must enlarge her or his vocabulary mastery.

Next, 3 respondents said that "I have to read always an English article", "maybe if I always read an English article every day, "I could be familiar with many word in the same meaning". "An English Article has helped me because it gains my vocabulary. It will be conclude that the respondents have to read an English article to gain many information and vocabulary. And it supported by the statement from Krashen (2004:11) when children or less literature adults start reading for pleasure, however, good things will happen. Their reading comprehension will improve, and they will find difficult, academic style texts easier to read. Their writing style will 


\section{INTENSIVE JOURNAL}

http://ojs.uniska-bjm.ac.id/index.php/EJB

E-ISSN 1513567470

improve, and they will be better able to writing prose in a style that is acceptable to school and business. Then the suggestions from 2 students are "I have to be brave in writing, because I think I able to write clearly, concise and communicative correspondence, but sometimes I felt unconfident with my vocabulary and sentences. The suggestions is to brave to mistakes.

And the last 3 respondents' suggestions are "Experience is the best teacher, so if I could write Business English Correspondence every day or try to write always even one hour in a day, I am sure I could be able to write”. That statements are similar with the theory of Langan (2011) writing is a skill, it makes sense that the more they practice to write, the better their writing will be. The suggestion is improving by writing Business English Correspondence daily.

\section{CONCLUSION}

The most of the respondent agree that top five difficulties of Writing Business English Correspondence are I cannot use wide range of vocabulary in my Business English Letter, then I cannot use appropriate words or business words in my business letter, I cannot make my business letter clear, concise and communicate, then in body of letter, I cannot make second paragraph or Main Part of the Letter states the main idea or the reason for writing. I can't make it clear, concise, complete, and to the point, and I did

not know the grammar or tenses that I used. These difficulties are from their self and they disagree with the statements of I think my lecturer has not explain the material thoroughly and I'm not always use spell check and recheck when my writing business letter before submit to the lecturer. The respondent suggestions to improve their Writing Business English Correspondence are about vocabulary and their learning English method. They realized that they supposed to change their learning method, for example find out more enlarge of vocabulary meaning, often in reading English article, try to write Business English Correspondence and the last is to brave in mistakes, because they feel experience is the best teacher. 
DIFFICULTIES IN WRITING BUSINESS ENGLISH CORRESPONDENCE AT FOURTH

SECRETARY SEMESTER STUDENTS

NETI ROSIANA FADILAH

\section{REFERENCES}

Ashley, A. A. Handbook of commercial Correspondence. Oxford: OUP, 1992,34.

Cameron, D. (2001). Teaching Language to Young Learnes. Cambridge: Cambridge University Pers.

Insley, Robert. (2016). Business Letters \& Memos from Communicating in Business 2nd Edition. Property of Kendall Hunt Publishing.

Krashen, S. (2011). Free Voluntary Reading. California: Libraries Unlimited

Lougheed, Lin. (2003). Business Correspondence “A Guide to Everyday Writing”. Intermediete. New York: Longman

Muth'im, Abdul. (2007). DEVELOPING WRITING SKILL (From Theory to Practice). Banjarmasin: Jurusan Pendidikan Bahasa dan Seni Fakultas Keguruan dan Ilmu Pendididkan Universitas Lambung Mangkurat.

Sugiono. (2009). Metode Penelitian Kualitatif dan R\&D, Bandung : Alfabeta

Wardaugh, Ronald. (1998). An Introduction to Socio Linguistic. Third Edition. Oxford: Blackwell Publisher

Yule, George. (1996). Pragmatics. Oxford: Oxford University Press 